\title{
STRATEGI PENGEMBANGAN USAHA PEREMPUAN PELAKU UMKM DI KOTA AMBON
}

\author{
Bin Raudha Arif Hanoeboen \\ Fakultas Ekonomi Universitas Pattimura \\ Jln. Ir. M. Putuhena Kampus Poka Unpatti Ambon 97116 \\ E-mail: raudhaarif@yahoo.co.id/ HP. 081334591609

\section{Pudjihardjo \\ Sasongko} \\ Fakultas Ekonomi Universitas Brawjaya \\ J1. Veteran Malang 65145
}

\begin{abstract}
Research explores the most appropriate strategies which are made to develop women as UMKM Actor at Ambon City. The field review shows that for business development, the UMKM Actor must increase the entrepreneurship capability by emphasizing on the empowerment aspect of public economic because both are very important features for UMKM Actor at Ambon City. Research method is qualitative method. Data collection techniques involve interview, observation and documentation. The first informant is selected by purposive sampling. Next informant is selected through snowball sampling, while the final informant is based on the satiation rate of information, in wich no more variance of information is required. Data collected from the field are analyzed using Spradley Model. Domain analysis technique is the first step, and continued by taxonomy technique. Interview, observation and documentation are conducted over the artisan of pearl mollusk, fish trader and entrepreneur of fumed fish, who are mostly women. The supporting interview and documentation from related agencies at Ambon City are also considered. Research recommends the business development strategy which is expected to be the guide to the similar business development works and the empowerment effort for the women of UMKM Actor at Ambon City.
\end{abstract}

Keywords: Strategi pengembangan usaha, perempuan pelaku UMKM, wirausaha, ekonomi rakyat.

Usaha Mikro Kecil dan Menengah memiliki posisi penting, bukan saja dalam penyerapan tenaga kerja dan kesejahteraan masyarakat di daerah, dalam banyak hal mereka menjadi perekat dan stabilisator dalam masalah kesenjangan sosial. Sehubungan dengan hal tersebut, maka perlu upaya untuk menumbuhkan iklim kondusif bagi perkembangan UMKM dalam mempercepat pembangunan daerah. Rendahnya resistensi oleh krisis ekonomi bagi kelompok industri kecil menengah, termasuk di dalamnya adalah industri berskala mikro, membuat kelompok ini mengalami 
perkembangan justru di saat industri besar mengalami penurunan. Dengan demikian maka industri kecil khususnya yang dijalankan oleh perempuan diharapkan mampu mengambil peran sebagai break-through bagi bangkitnya kembali sektor indusri di daerah.

Usaha Mikro Kecil dan Menengah (UMKM) patut diakui sebagai kekuatan strategis dalam percepatan pembangunan daerah, oleh karena pertumbuhan Usaha Mikro Kecil dan Menengah setiap tahun mengalami peningkatan, dimana berdasarkan data dari Biro Pusat Statistik jumlah UMKM di Indonesia pada tahun 2009 sebanyak 52,7 Juta unit, dan terbukti memberikan kontribusi 56,53\% terhadap PDB (Pendapatan Domestik Bruto) dan 97,30\% terhadap penyerapan tenaga kerja.

Fakta tersebut menunjukan bahwa Usaha Mikro, Kecil dan Menengah (UMKM) memainkan suatu peran yang sangat vital dalam pembangunan dan perkembangan perekonomian Indonesia. Di Indonesia UMKM sangat penting bukan hanya disebabkan karena kemampuannya dalam hal penyerapan tenaga kerja yang sangat banyak dibandingkan dengan kemampuan usaha besar, tetapi juga karena kemampuannya memberikan kontribusi bagi pembentukan dan pertumbuhan Produk Domestik Bruto (PDB) seperti yang diperlihatkan pada data tersebut di atas.

Para ekonom biasanya menyebutkan ada lima keadaan yang memungkinkan industri kecil dapat bertahan (Supratikno; dalam Yustika,2007:183). Pertama, usaha industri kecil bergerak dalam pasar yang terpecah-pecah (fragmented market). Kedua, usaha industri kecil menghasilkan produk-produk dengan karakteristik elastisitas pendapatan yang tinggi. Ketiga, usaha kecil memiliki heterogenitas yang tinggi, khususnya tekhnologi, sehingga indistri kecil dapat menghasilkan produk yang beraneka ragam. Keempat, usaha industri kecil tergabung dalam suatu cluster (sentra industri), sehingga mampu memanfaatkan efisiensi kolektif (modal sosial) misalnya dalam hal pembelian bahan baku, pemanfaatan tenaga kerja terampil, dan dalam hal pemasaran. Kelima, usaha-usaha industri kecil diuntungkan oleh kondisi geografis, yang membuat produk-produk industri kecil memperoleh proteksi alami karena pasar yang dilayani tidak terjangkau oleh produk-produk industri berskala besar.

Dari jumlah UMKM di Indonesia yang diperlihatkan tersebut perempuan sebagai pelaku UMKM memiliki jumlah yang cukup signifikan. Walaupun data mengenai keterlibatan perempuan dalam usaha mikro, kecil dan menegah masih sangatlah minim 
namun diyakini berdasarkan fakta yang ditemukan di lapangan diketahui bahwa mayoritas Usaha Mikro, Kecil dan Menengah ini dijalankan oleh perempuan, khususnya pada usaha-usaha home industri yang dikelola oleh rumah tangga-rumah tangga. Dilihat dari jumlah unit usahanya UMKM sangat banyak terdapat di semua sektor ekonomi dan kontribusinya sangat besar terhadap kesempatan kerja dan pendapatan, namun di sisi lain, ditemukan bahwa banyak usaha kecil dan menengah yang dikelola oleh perempuan banyak mengalami kendala di berbagai aspek usaha yang dijalankannya, sebagai antisipasi permasalahan, maka perlu dilakukan kajian mengenai bagaimana potensi Usaha Kecil Menengah yang dikelola kaum perempuan sebagai kontributor penetrasi ekonomi.

Khusus di Kota Ambon walaupun tidak ada data yang spesifik tentang usaha yang dijalankan oleh perempuan namun berdasarkan fakta yang ditemukan di lapangan bahwa mayoritas Usaha Mikro Kecil dan Menengah yang terdapat di Kota ini dikelola dan dijalankan oleh perempuan. Ketidaktersediaan data mengenai perempuan pelaku usaha mikro kecil dan menengah ini karena pendataan dilakukan tidak dispesifikasikan antara pelaku usah perempuan dan laki-laki. Ketidaktersediaan data yang lebih spesifik ini yang kemudian relatif menyebabkan perempuan pelaku usaha di Kota Ambon kurang mandapat perhatian dari pemerintah dan stake holder lainnya sehingga kurang mampu mengembangkan usahanya dengan baik walaupun usaha yang mereka jalankan rata-rata memiliki prospek yang positif untuk berkembang.

Melihat kondisi yang demikian maka dibutuhkan adanya strategi-strategi yang harus dirumuskan terutama yang berkaitan dengan upaya pengembangan usaha yang dijalankan oleh pelaku usaha khususnya perempuan pelaku usaha yang ada di Kota Ambon hal ini karena seorang pelaku usaha yang berhasil, membutuhkan strategi yang tepat untuk memaksimalkan sumber-sumber dalam menciptakan suatu nilai terhadap barang dan jasa. Berdasarkan latar belakang diatas maka yang menjadi permasalahan dalam penelitian ini adalah: " Strategi apa yang harus dilakukan demi pengembangan usaha perempuan pelaku UMKM di Kota Ambon melalui pemberdayaan entrepreneurship dan ekonomi kerakyatan"

Setiap tahunnya Indonesia melahirkan lebih dari 700.000 sarjana yang menganggur. Belasan juta penduduk Indonesia adalah pengangguran terbuka. Sementara itu jumlah wirausahawan hanya $0.18 \%$ dari total penduduk Indonesia, masih 
jauh tertinggal dibandingkan dengan Cina yang memiliki angka $2 \%$ atau bahkan Singapura dengan rasio 6-7\% adalah wirausahawan. Kurangnya jumlah perusahaan formal adalah salah satu titik lemah ekonomi Indonesia. Untuk itu kemandirian adalah kata kunci untuk kemajuan bangsa.

Banyaknya perusahaan yang tumbuh diawali model UKM (Usaha Kecil Menengah) atau small medium enterprise yang dimotori oleh semangat kewirausahaan (entrepreneur spirit) yang tangguh sebagai penggerak aktivitas perekonomian dapat menciptakan lapangan kerja. Keberlanjutan pertumbuhan jumlah perusahaan memerlukan jumlah pengusaha yang juga terus tumbuh. Risiko roda perekonomian yang hanya mengandalkan sejumlah kecil pengusaha tampak jelas pada krisis Asia Timur tahun 1997-1998. Pada saat krisis itu, ekonomi rakyat diselamatkan oleh usaha mikro kecil dan menengah yang bertahan. Menyadari akan kurangnya kemampuan entrepreneurship yang dimiliki oleh mayoritas pelaku UMKM di Indonesia khususnya perempuan maka sangat mendesak untuk ditingkatkannya program-program pemberdayaan dalam rangka untuk meningkatkan kemampuan entrepreneurship yang wajib dimiliki oleh semua pelaku usaha dalam rangka untuk mengembangkan usahanya.

\section{Pemberdayaan Ekonomi Masyarakat}

Pemberdayaan ekonomi masyarakat menurut Hutomo (2000), adalah penguatan pemilikan faktor-faktor produksi, penguatan penguasaan distribusi dan pemasaran, penguatan masyarakat untuk mendapatkan gaji/upah yang memadai, dan penguatan masyarakat untuk memperoleh informasi, pengetahuan dan ketrampilan, yang harus dilakukan secara multi aspek, baik dari aspek masyarakatnya sendiri, mapun aspek kebijakannya.

Menurut Sumodiningrat (1999), perekonomian rakyat adalah perekonomian yang diselenggarakan oleh rakyat. Perekonomian yang deselenggarakan oleh rakyat adalah bahwa perekonomian nasional yang berakar pada potensi dan kekuatan masyarakat secara luas untuk menjalankan roda perekonomian mereka sendiri. Pengertian rakyat adalah semua warga negara. Pemberdayaan ekonomi rakyat merupakan usaha untuk menjadikan ekonomi yang kuat, besar, modern, dan berdaya saing tinggi dalam mekanisme pasar yang benar. Karena kendala pengembangan ekonomi rakyat adalah 
kendala struktural, maka pemberdayaan ekonomi rakyat harus dilakukan melalui perubahan struktural.

Perubahan struktural yang dimaksud adalah perubahan dari ekonomi tradisional ke ekonomi modern, dari ekonomi lemah ke ekonomi kuat, dari ekonomi subsisten ke ekonomi pasar, dari ketergantungan ke kemandirian. Langkah-langkah proses perubahan struktur, meliputi: (1) pengalokasian sumber pemberdayaan sumberdaya; (2) penguatan kelembagaan; (3) penguasaan teknologi; dan (4) pemberdayaan sumberdaya manusia. Pemberdayaan ekonomi rakyat, tidak cukup hanya dengan peningkatan produktivitas, memberikan kesempatan berusaha yang sama, dan hanya memberikan suntikan modal sebagai stumulan, tetapi harus dijamin adanya kerjasama dan kemitraan yang erat antara yang telah maju dengan yang masih lemah dan belum berkembang.

Pada era otonomisasi saat ini, konsep pengembangan ekonomi kerakyatan harus diterjemahkan dalam bentuk program operasional berbasiskan ekonomi domestik pada tingkat kabupaten dan kota dengan tingkat kemandirian yang tinggi. Namun demikian perlu ditegaskan bahwa pengembangan ekonomi kerakyatan pada era otonomisasi saat ini tidak harus ditejemahkan dalam perspektif territorial. Tapi sebaiknya dikembangkan dalam perspektif 'regionalisasi' di mana di dalamnya terintegrasi kesatuan potensi, keunggulan, peluang, dan karakter sosial budaya.

\section{METODE}

Penelitian tentang strategi yang harus dilakukan demi pengembangan usaha perempuan pelaku UMKM di Kota Ambon melalui pemberdayaan entreprneurship dan pemberdayaan ekonomi rakyat ini dilakukan dengan menggunakan metode penelitian kualitatif. Jenis penelitian yang digunakan dalam penelitian ini adalah penelitian deskriptif. Dalam penelitian kualitattif, peneliti sendiri yang menjadi instrument utama yang terjun ke lapangan dan berusaha sendiri mengumpulkan informasi melalui observasi dan wawancara. Wawancara yang dilakukan bersifat terbuka dan tak terstruktur. Untuk memudahkan pengumpulan data menggunakan alat bantu berupa catatan lapangan, maupun foto dan pedoman wawancara, dalam penelitian ini dilakukan terhadap perempuan pelaku usaha kerajinan kerang mutiara dan usaha pengolahan ikan asap di Kota Ambon. Dalam menganalisis data hasil penelitian yang diperoleh, peneliti menggunakan teknik dengan model Spradley, seperti yang diuraikan oleh Sugiyono 
(2005), yakni teknik analisis domain (domain analysis) yang merupakan langkah pertama dalam penelitian kualitatif, dan dilanjutkan dengan teknik taksonomik (Taxonomic Analysis).

\section{HASIL DAN PEMBAHASAN}

Seorang wirausaha yang berhasil, membutuhkan strategi yang tepat untuk memaksimalkan sumber-sumber dalam menciptakan suatu nilai terhadap barang dan jasa. Dalam upaya pengembangan usaha pelaku UMKM perempuan di Kota Ambon melalui pemberdayaan entrepreneurship dan ekonomi kerakyatan, penelitian dilakukan terhadap usaha pengolahan ikan asap dan sentra kerajinan kerang mutiara dimana kedua jenis usaha ini mayoritas dijalankan oleh perempuan dan paling banyak menyerap tenaga kerja perempuan, maka dirumuskan strategi-strategi yang perlu dilakukan di antaranya:

\section{Penguatan dan Pengembangan Pasar}

Selama ini pengusaha UMKM perempuan di Kota Ambon dalam memasarkan produknya masih terpusat pada tempat atau lokasi keberadaannya saja. Kalau pun produk yang dihasilkan memiliki konsumen yang berasal dari daerah yang berbeda, namun untuk mendapatkannya, konsumen sendirilah yang langsung mendatangi lokasi dimana usaha tersebut dijalankan. Biasanya pembeli dari luar Kota Ambon menitipkan kepada famili atau kenalan mereka untuk membeli dan mengirimnya.

Hasil observasi yang dilakukan terhadap pengusaha ikan asap yang mayoritas dijalankan oleh perempuan, menunjukkan bahwa beberapa pembeli ikan asap adalah untuk mengirimnya ke luar kota sebagai oleh-oleh untuk keluarga di daerah lain. Oleh karena itu, sesungguhnya produk ikan asap ini bukan hanya di kenal di Kota Ambon saja, bahkan melalui konsumen produk ini telah disebarkan hingga daerah lain. Kondisi ini sesungguhnya merupakan sebuah peluang bagi pengusaha untuk mengembangkan pemasarannya yang sebelumnya hanya di Kota Ambon saja, mungkin ke depannya dapat menyebar ke daerah lainnya di tanah air sebagai produk makanan khas dari Kota Ambon.

Perluasan terhadap zona pasar dengan mengembangkannya ke wilayah yang belum terlayani oleh produk serupa merupakan strategi yang efektif, mengingat 
minimnya pesaing yang ada. Namun demikian kondisi pasar tanpa pesaing bukan merupakan jaminan akan keberhasilan pasar, tentunya pengusaha harus mengetahui selera, karakter dari target konsumennya secara tepat, sehingga produk yang dilempar ke pasar, adalah tepat sasaran. Dengan demikian maka ketersediaan informasi yang memadai mengenai kebutuhan akan produk yang dihasilkan sangat dibutuhkan dalam rangka pengembangan pasar. Untuk itu maka diperlukan sistem informasi pasar (market intelligent) yang berfungsi sebagai penyedia informasi bagi pengusaha tentang kebutuhan dan kondisi pasar. Informasi tentang pasar ini diperoleh dari data yang merupakan feedback atas kebijakan perusahaan.

Produk-produk dari UMKM yang dari Kota Ambon, belum begitu menjamah pasar regional dan global. Padahal produk-produk mereka, umumnya merupakan jenis produk yang bersifat khas, sehingga sulit untuk diperoleh di daerah lainnya. Kondisi ini merupakan sebuah peluang bagi pelaku UMKM untuk mengembangkan pasar ke wilayah yang belum terlayani. Meskipun demikian, strategi perluasan pasar memiliki resiko yang cukup besar. Hal tersebut disebabkan karena belum ada parameter acuan yang jelas dalam memberikan informasi terkait daya serap pasar. Namun tentunya pelaku usaha sudah melakukan perhitungan dan perkiraan-perkiraan, atas fakta bahwa produk-produk yang mereka hasilkan sudah dikenal di daerah yang dituju. Ikan asap dan kerajinan kerang mutiara misalnya, walaupun khas dari Maluku, produk ini sudah dikenal di berbagai daerah. Khusus untuk kerajinan kerang mutiara, bahkan sangat laris dibeli oleh para turis. Oleh karena itu, maka produk-produk UMKM perempuan di Kota Ambon seperti kerajinan kerang mutiara dan produk lainnya, sesungguhnya memiliki potensi untuk memiliki teritorial pasar yang lebih luas dan tidak hanya terfokus di Kota Ambon saja.

Untuk kerajinan kerang mutiara sendiri sudah dikenal diseantaro nusantara, bahkan digemari oleh turis atau pelancong yang kebetulan singgah di Kota Ambon. Mengetahui kenyataan bahwa produk ini sudah dikenal hingga luar Kota Ambon, maka tentunya dibutuhkan analisa yang tepat untuk menentukan daerah manakah yang paling potensial untuk menjadi wilayah pengembangan pasar. Selanjutnya adalah merencanakan langkah taktis yang tepat agar dapat meminimalisasi resiko kerugian yang disebabkan karena kebijakan perluasan pasar tersebut. Salah satu langkah yang dapat dilakukan adalah dengan pengaturan terhadap volume pasokan dari produk yang 
hendak dilempar ke pasar baru tersebut. Dalam mengatur volume pasokan produk ini, tentunya menggunakan perhitungan secara statistik untuk mendapatkan informasi terkait peluang resiko terkecil yang bisa terjadi. Di samping itu perusahaan harus tetap memperhatikan standar kuantitas produk yang disyaratkan untuk memperoleh informasi tentang daya serap pasar.

Dengan menjalankan prinsip tersebut maka apabila pembukaan zona pasar yang baru tersebut ternyata tidak mampu untuk berkembang menjadi pasar yang efektif bagi produk yang ditawarkan, maka kerugian yang dialami tentunya tidak akan melebihi rencana kerugian maksimal yang diperhitungkan sebelumnya. Sebaliknya jika perluasan zona pasar ternyata memberikan peluang untuk dikelola sebagai pasar baru maka pengusaha harus dapat menjaga keseimbangan dan kesinambungan distribusi produk di pasar sehingga dapat memosisikan perusahaan tersebut sebagai pemimpin pasar (market leader).

\section{Efisiensi Model Promosi}

Jika ditinjau dari segi mutu dan kualitas, produk-produk dari UMKM yang ada di Kota Ambon bisa dikatakan dapat bersaing dengan produk-produk sejenis lainnya yang mampu menembus pasar yang lebih luas. Dalam hal ini promosi produk memiliki peran yang dominan. Untuk memperoleh hasil yang maksimal, promosi harus dilakukan secara profesional dalam artian pengusaha harus dapat memilih bentuk promosi yang memiliki efektifitas dan efisiensi tinggi. Untuk itu beberapa bentuk yang perlu dilakukan oleh UMKM di Kota Ambon adalah: Pertama, membuat website, e-mail atau bener iklan produk melalui internet. Bentuk promosi secara online seperti ini cukup efektif dalam daya jangkau konsumen. Karena dengan biaya yang relatif terjangkau, dengan berada di tempatnya saja pengusaha dapat mempromosikan produknya ke seluruh konsumen maupun perusahaan lain yang berada dalam jangkauan jaringan internet. Profil dari produk dapat diakses via online, transaksi dilakukan melalui transfer rekening dengan kode pembelian dan kemudian barang atau produk dikirimkan ke alamat konsumen. Kelemahan bentuk ini adalah karena banyaknya perusahaan fiktif yang bertebaran di dunia maya sehingga menyebabkan kepercayaan bisnis menjadi rendah. Namun setidak-tidaknya untuk memperkenalkan produk dan jenis usaha kepada publik, media ini sangat efektif untuk dilakukan. 
Kedua, turut serta dalam kegiatan pameran. Pameran merupakan bentuk promosi dimana pengusaha secara langsung bertemu dengan calon konsumennya dalam jumlah yang cukup banyak. Target utama dari pameran ialah bukan mendapatkan pembelian yang sebanyak-banyaknya dalam even tersebut, tetapi justru setelah pameran dilakukan perusahaan dan produk yang dipamerkan dapat meraup konsumen sebesarnya-besarnya. Untuk itu desain penampilan dan pemilihan produk khususnya yang memiliki keunikan atau yang merupakan keunggulan produk harus ditampilkan sehingga dapat diterima oleh konsumen pada saat pameran. Kendala dalam kegiatan promosi ini adalah karena pengusaha UMKM rata-rata memiliki kelemahan finansial sehingga kesulitan dalam hal pembiayaan kegiatan tersebut khususnya pada persoalan teknis seperti bentuk, tempat dan lama kegiatan. Komponen biaya yang dikeluarkan untuk kegiatan promosi di luar modal kerja adalah: a) sewa tempat; b) Biaya administrasi; c) biaya pengepakan; d) biaya pengangkutan dan biaya petugas UMKM yang ikut dalam pameran (penjaga pameran). Untuk itu kegiatan promosi dalam bentuk ini harus dipersiapkan secara matang melalui perencanaan strategi model promosi.

Ketiga, Desain kemasan, Umumnya kemasan untuk produk-produk yang dihasilkan oleh UMKM di Kota Ambon masih sederhana. Kemasan yang digunakan masih sekedar memenuhi kebutuhan fungsionalnya saja. Sedangkan unsur pasar berupa daya tarik terhadap konsumen dalam desain kemasan belum menjadi perhatian. Desain kemasan memeliki kemampuan yang cukup besar dalam mempengaruhi keputusan pelanggan. Oleh karena itu diperlukan keseriusan untuk mendesain model kemasan yang menarik di mata pelanggan. Dalam desain kemasan agar dapat memiliki daya terik terhadap konsumen, maka faktor-faktor yang perlu diperhatikan adalah bentuk fisik kemasan, bahan yang digunakan, warna dan tulisan. Secara keseluruhan desain kemasan harus memiliki kesan yang mewakili keunggulan produk yang dijual. Oleh sebab itu dalam desain kemasan antara bentuk, warna, jenis dan ukuran tulisan harus konsisten terhadap tema yang sama dari produk. Sementara bahan yang digunakan untuk kemasan harus disesuaikan dengan jenis produk. Khususnya untuk produk ikan asap dan produk makanan lainnya, tentunya sangat mengutamakan jaminan kesehatan dan kebersihannya. Jenis bahan yang digunakan ini secara keseluruhan dipengaruhi oleh kebutuhan waktu bertahan produk di pasar. 


\section{Pendampingan dan Pembinaan}

Salah satu persoalan yang sering dihadapi oleh pelaku UMKM perempuan di Kota Ambon adalah kurangnya pendampingan dan pembinaan dalam program-program pemberdayaan UMKM. Akhirnya program-program pemberdayaan yang dilakukan baik oleh pemerintah, perguruan tinggi maupun LSM dan lembaga lainnya, tidak dapat menyentuh dan menjawab akar permasalahan yang sesungguhnya. Kegiatan pelatihanpelatihan yang dilakukan, kebanyakan tidak ditindaklanjuti dengan pendampingan dan pembinaan secara kontunyu sehingga hasilnya tidak maksimal. Di mana-mana setiap pengusaha menginginkan adanya laba yang memadai dalam usaha yang dijalankan sehingga dapat menunjang perputaran usaha. Namun ternyata banyak pengusaha yang mendapatkan persoalan dalam pencapaian target pendapatan. Akibatnya ketersediaan dana untuk menjamin keberlangsungan produksi pun mengalami kekurangan.

Pelaku UMKM sering mengalami persoalan yang terkait dengan modal. Bahkan seringkali menyalahkan pemerintah, karena kurang proaktif dalam membantu menyelesaikan persoalan tersebut. Tapi, hal ini kelihatannya tidak sebanding dengan data-data di lapangan terkait program pemodalan bagi UMKM yang belakangan ini dengan gencar dilakukan oleh lembaga bantuan keuangan yang ada di Kota Ambon. Salah satu kelemahan yang dihadapi oleh pelaku UMKM di Kota Ambon saat ini karena disebabkan oleh kurangnya pendampingan dan pembinaan. Pembinaan di bidang manajemen yang kurang terhadap UMKM berakibat pada gagalnya program pemberdayaan itu sendiri. Maka pendampingan dan pembinaan dalam hal penataan sistem manajemen yang baik dan proporsional adalah sangat dibutuhkan bagi setiap pelaku usaha.

Melalui pendampingan dan pembinaan dijelaskan fungsi setiap elemen dalam perusahaan. Panduan inilah yang menjadikan dasar dalam pelaksanaan operasional perusahaan, agar proses perencanaan, pelaksanaan dilapangan, evaluasi dan pelaporan dapat dijalankan dengan baik. Beberapa aspek dalam UMKM yang perlu mendapatkan pendambingan dan pembinaan antara lain: (1) Keuangan (penganggaran, laporan, pembelian, dll), (2) Produksi (pengerjaan, quality control, pengepakan, pemilihan bahan baku, dll), (3) Pemasaran (penerapan strategi pemasaran, kontroling, laporan penjualan, 
dll), (4) Operasional (Peraturan Perusahaan, Budaya Kerja, Jam Kerja, dll) dan (4) SDM (sistem rekrutmen, penggajian dan tunjangan, dll).

\section{Membentuk Keunikan atau Kekhasan sebagai Keunggulan Produk}

Strategi ini menekankan pada upaya perubahan karakteristik produk yang berbasis pada inovasi dan kreatifitas. Tujuannya adalah menciptakan karakteristik produk sehingga memiliki ciri khas khusus (speciality goods) yang membedakannya dengan produk serupa yang ada di pasar. Dalam persaingan untuk mendapatkan tempat dan penerimaan pasar yang positif maka memiliki produk yang berciri khas khusus adalah penting dalam karena dengan karakter yang berbeda dari produk-produk sejenisnya, membuat produk yang ditawarkan akan menjadi sebuah varian tersendiri bagi konsumen. Ini penting dalam proses pembentukan brand di benak konsumen.

Ciri khusus yang dimiliki produk ini pula merupakan sebuah nilai tambah atau keunggulan produk, karena tentunya tidak dimiliki oleh produk-produk sejenisnya yang ada di pasar. Dengan keunggulan yang dimiliki, maka akan memperbesar daya tarik pada konsumen untuk membeli produk tersebut. Kelebihan lain yang juga diperoleh lewat strategi ini ialah, produk akan lebih mudah diingat oleh konsumen sehingga berpeluang menjadi pilihan pertama bagi konsumen ketika mendatangi pasar. Jika permintaan mengalami peningkatan, maka akan secara alamiah meningkat pula harga produk. Peningkatan harga produk ini sesuai dengan perbandingan perubahan permintaan pasar agar laju pembelian masih berada pada rasio yang normal sehingga tidak merubah siklus pasar dan produksi.

Jika tidak ada peningkatan harga produk ketika permintaan meningkat drastis, maka keadaan ini akan menyebabkan adanya titik kulminasi atau kejenuhan permintaan pasar yang berakhir pada berhentinya permintaan produk. Selanjutnya produksi pun menjadi tertunda dan mempengaruhi siklus secara keseluruhan. Adapun beberapa sektor yang dapat dikembangkan untuk menemukan keunikan produk di antaranya adalah, Pertama, Menciptakan manfaat, dalam hal ini pengusaha harus menemukan item tambahan yang dapat memperkuat atau menambah fungsi atau manfaat dari produk itu sendiri. Cara ini bisa dilakukan dengan memadukan beberapa produk lain menjadi sebuah produk yang lebih variatif. Misalnya kerajinan kerang mutiara dan jam dinding yang bisa dipadukan atau untuk produk UMKM lainnya. Dengan demikian akan 
memembuat konsumen merasa diuntungkan dengan mendapatkan beberapa fasilitas atau manfaat dalam satu produk.

Kedua, Meningkatkan inovasi. Perusahaan yang dapat bertahan dalam persaingan pasar jangka panjang, adalah perusahaan yang selalu melakukan inovasi terhadap produk yang dihasilkan. Inovasi dapat dilakukan jika adanya evaluasi mengenai persepsi konsumen terhadap produk. Dengan menggunakan data tersebut maka pengusaha akan mengetahui kekurangan dan kelebihannya menurut konsumen sehingga inovasi yang dilakukan dapat sesuai dengan permintaan. Ketiga, Beradaptasi dengan lingkungan sosial ekonomi pelanggan. Langkah ini dilakukan untuk mendapatkan penerimaan sosial terhadap produk. Strategi ini bisa berupa desain kemasan, nama, manfaat dan lain sebagainya, sehingga produk tersebut bisa langsung menyesuaikan diri dengan kondisi permintaan pasar yang ada. Salah satu contohnya adalah kerajinan kerang mutiara dalam bentuk kaligrafi di Desa Batu Merah.

Keempat, Menyediakan sesuatu yang berharga. Seorang entrepreneur yang berhasil, selalu memperhatikan nilai-nilai yang berlaku dimasyarakat. Dia akan mengetahui manakah hal-hal yang oleh masyarakat bernilai tinggi. Maka dalam pemilihan jenis produk, akan memprioritaskan untuk menyajikan apa yang dianggap bernilai oleh masyarakat atau sekurang-kurangnya nilai-nilai itu turut tersisipkan di dalam produk. Dengan menerapkan langkah-langkah di atas secara konsisten dan berkesinambungan maka perusahaan akan dapat terus bertahan pada persaingan pasar dalam jangka panjang.

\section{Koperasi Wanita sebagai Wadah bagi Perempuan Pelaku UMKM}

UMKM yang berhasil ialah yang memiliki kemampuan untuk memanfaatkan segala potensi yang ada baik, internal maupun eksternal yang berkaitan dengan usaha yang dijalankan. Selama ini, persoalan-persoalan yang dihadapi pengusaha perempuan ini dalam UMKM yang dijalankan basih dipengaruhi kebijakan eksternal serta modal sosial yang ada di masyarakat. Sementara upaya dan langkah-langkah kreatif dari pelaku UMKM itu sendiri yang mampu melahirkan sistem solusi bagi persoalan mereka semisal koperasi wanita, dipandang perlu untuk digalang.

Koperasi wanita diharapkan dapat menjadi wadah pengembangan entrepreneurship bagi pengusaha UMKM perempuan dalam mengatasi persoalan usaha 
yang dihadapi. Adapun beberapa persoalan yang dapat dioptimalkan solusinya melalui koperasi wanita di antaranya:

Pertama, Persoalan permodalan. Permodalan merupakan faktor yang sangat mendasar dalam menunjang aktivitas perusahaan secara keseluruhan. Keterbatasan pada pemodalan dapat mengganggu kelancaran proses produksi bahkan melumpuhkan perusahaan. Kebutuhan akan pemodalan ini adalah untuk memenuhi berbagai keperluan perusahaan seperti pengadaan bahan baku, proses produksi, penggantian peralatan dan dalam rangka penambahan sumber daya manusia. Untuk itu pengusaha perlu mengembangkan koperasi perempuan sebagai solusi terhadap persoalan pemodalan.

Salah satu persoalan teknis yang muncul disebabkan oleh ketebatasan permodalan adalah dalam hal penyediaan bahan baku. Keaadaan ini terjadi ketika pengusaha tidak memiliki modal yang cukup untuk membeli bahan baku. Maka melalui koperasi wanita para pelaku UMKM dapat memperoleh bantuan pemodalan yang diambil dari dana kas koperasi yang bersumber dari iuran anggota. Koperasi wanita juga dapat menjadi wadah dalam menjembatani pengusaha dan penyedia bahan baku. Dengan memanfaatkan modal sosial yang dimiliki berupa kerpercayaan, maka efek pemanfaatan modal sosial dalam pengembangan usaha dapat dirasakan secara komunal melaui koperasi.

Agar modal sosial berupa kepercayaan ini dapat memberikan solusi terhadap pemenuhan bahan baku secara efektif dan dipertahankan dalam jangka panjang, maka pemanfaatan modal sosial berupa kepercayaan tersebut mestilah didukung dengan perencanaan yang tepat, sehingga tidak menyebabkan kerugian bagi kedua belah pihak yang pada akhirnya melunturkan nilai kepercayaan itu sendiri.

Kedua, Hubungan antar pengusaha UMKM perempuan. Menjalankan usaha UMKM di Kota Ambon seperti sentra kerajinan kerang mutiara, pengelolaan ikan asap dan yang lainnya tentu tidak terlepas dari adanya persaingan dalam memperebutkan pasar. Keadaan yang demikian jika tidak didukung oleh pola persaingan yang sehat, maka tentunya akan berakibat pada tidak kondusifnya perkembangan usaha. Untuk mencegah terjadinya hal-hal yang merugikan pengusaha dalam persaingan pasar, maka kehadiran koperasi wanita mengambil peran dalam mengakomodir para pengusaha UMKM dalam memasarkan produknya ke konsumen. Koperasi wanita dapat membantu pengusaha melalui hubungan kerja sama dengan agen penyalur tetap yang akan mendorong produk kerajinan mereka terserap oleh pasar. Dengan demikian maka 
pengusaha dapat mengetahui angka perkiraan pembelian sehingga volume rata-rata kecepatan produksi dalam satu siklus pemasaran produk dapat direncanakan.

Ketiga, Memberikan Kepuasan kepada konsumen melalui jaminan kualitas. Kualitas dari sebuah produk adalah unsur vital dalam menentukan suatu produk dapat bertahan di pasar dalam jangka waktu yang panjang. Seiring dengan perkembangan informasi, konsumen yang masih awam pun akhirnya akan mengetahui mana produk yang berkualitas dan yang bukan. Produk-produk yang dihasilkan oleh UMKM umumnya menggunakan peralatan dan teknologi yang sederhana serta bahan baku yang berasal dari hasil alam. Dengan demikian yang berperan besar dalam menghasilkan produk yang berkualitas di sini adalah unsur manusianya. Maka sumberdaya manusia yang terampil dan kreatif memiliki peran kunci dalam dalam menghasilkan produk yang berkualitas.

Koperasi wanita juga berperan dalam pengembangan keterampilan anggotanya pada setiap bagian, apakah proporsional ataukah tidak antara kemampuan pekerja dengan tingkat kesulitan pekerjaan. Untuk bagian-bagian pekerjaan yang membutuhkan keterampilan khusus, maka pengusaha haruslah selektif dalam merekrut tenaga kerja dengan mengutamakan keahlian dan kompetensi. Jangan sampai produk dihasilkan hanya asal jadi tanpa mengutamakan kepuasan konsumen atas mutu dan kualitas produk.

Keempat, Memperluas Interaksi Sosial untuk Membentuk Jaringan Kondisi kultural masyarakat di Kota Ambon yang memiliki interaksi sosial yang terbuka merupakan sebuah peluang bagi pelaku UMKM perempuan untuk membangun jaringan sosial yang luas dalam menunjang keberhasilan usaha. Terutama bagi UMKM yang menjalankan usaha sebagai usaha rakyat, jaringan merupakan faktor yang memegang peran signifikan dalam keberhasilan pemasaran. Untuk menunjang keberlangsungan usaha yang dijalankan, maka efektifitas jaringan melalui koperasi wanita perlu dimaksimalkan. Pada pelaku UMKM perempuan di Kota Ambon, didapati komunitas jaringan yang perlu dikelola oleh koperasi wanita sebaik-baiknya agar memberikan kontribusi positif terhadap perkembangan usaha. Pengusaha harus mempersiapkan kemampuan untuk melakukan penetrasi pasar, ekspansi pasar, diversifikasi produk dan jasa, integrasi regional atau ekspansi usaha. Maka yang perlu diperhitungkan secara cermat oleh pengusaha adalah: (a) Besar penganggaran yang diperlukan untuk mencapai 
pasar; (b) Melakukan pemetaan terhadap posisi strategis perusahaan dalam persaingan di pasar; (c) Menginventarisir berbagai peluang yang mungkin untuk dikembangkan sebagai strategi keunggulan perusahaan.

\section{Selalu Aktif Secara Kontinyu untuk Memperkuat Keunggulan Produk}

Perusahaan yang telah berhasil dipasar memiliki keunggulan produk yang lebih baik dibandingkan dengan produk sejenis lainnya. Namun acuan nilai keunggulan produk yang berlaku di pasar selalu bersifat dinamis. Standar nilai yang menyebabkan suatu produk menjadi unggul, sewaktu-waktu dapat mengalami perubahan. Hal ini menyebabkan perubahan pada produk yang unggul itu pula. Untuk itu perusahaan harus selalu mengikuti perkembangan apa yang terjadi dan secara serius mengupgrade keunggulan produknya agar selalu up to date di pasar.

Perusahaan harus meningkatkan pelayannya agar dapat menopang keunggulan strategi yang dimiliki dan untuk memodifikasi strategi dalam menghadapi perubahan permintaan pelanggan. Banyak perusahaan yang berhasil dan menguasai pasar tetapi keberhasilan yang mereka capai hanya bersifat temporal atau sementara saja. Memang strategi yang mereka gunakan untuk mencapai keberhasilan tersebut adalah tepat ketika itu. Namun yang tidak disadari oleh perusahaan ini adalah bahwa tantangan dan perspektif pasar sangatlah dinamis, sehingga bisa menyebabkan langkah stategis yang dilakukan di suatu waktu tidak lagi relevan di waktu yang berbeda.

Sebuah strategi tidak dapat dipertahankan di pasar selama-lamanya oleh pengusaha. Karena perubahan kondisi pasar adalah merupakan sebuah konsekwensi logis dari sebuah perkembangan, maka strategi yang dilakukan oleh perusahaan pun harus menyesuaikan diri dengan perubahan yang ada. Namun kebanyakan perusahaan tidak memiliki kejelian yang cukup baik untuk mengetahui perubahan yang sebenarnya. Akhirnya mereka mengambil kebijakan strategis yang ternyata keliru dan berakibat pada ruginya perusahaan. Oleh sebab itu dibutuhkan kecermatan dalam membaca perubahan pasar, sehingga dalam menuangkan kondisi objektif pasar ke dalam stretegi dan taktis perusahaan dalam mencapai keberhasilan perusahaan akan tepat dengan kebutuhan pasar atau konsumen. 


\section{KESIMPULAN DAN SARAN}

\section{Kesimpulan}

Berdasarkan hasil analisis dan pembahasan pada bab sebelumnya, diperoleh kesimpulan bahwa, dalam rangka untuk meningkatkan usaha perempuan pelaku UMKM di Kota Ambon diketahui telah dilakukan melalui berbagai upaya yang diharapkan mampu membawa perkembangan kearah yang lebih baik, mengingat keberadaan UMKM itu sendiri di Kota Ambon memiliki jumlah yang sangat banyak dan merata hampir pada semua aspek usaha, walaupun jumlahnya yang cukup banyak namun ternyata kontribusinya sendiri masih cukup kecil dibandingkan oleh usaha besar, hal ini karena UMKM khususnya yang dikelola oleh perempuan di Kota Ambon ini tidak menunjukan perkembangan yang berarti kendati usaha mereka telah berjalan cukup lama. Untuk menjawab permasalahan tersebut maka penulis mencoba menawarkan berbagai strategi pengembangan usaha dengan memanfaatkan kemampuan dan pengetahuan entrepreneurship dengan konsep pemberdayaan ekonomi kerakyatan yang diharapkan mampu menjawab berbagai permasalahan yang dihadapi oleh pelaku UMKM di Kota Ambon.

\section{Saran}

Strategi yang tepat diharapkan dapat menjawab berbagai permasalahan yang dihadapi oleh pelaku UMKM di Kota Ambon, untuk itu disarankan kepada pemerintah dan stake holder agar lebih meningkatkan keberpihakan kepada pelaku UMKM ini mengingat peran mereka yang sangat besar terhadap pembangunan ekonomi daerah, melalui program-program pemberdayaan yang diharapkan mampu meningkatkan pengetahuan dan kemampuan entrepreneurship serta pemberdayaan ekonomi rakyat yang merupakan modal dasar bagi mereka untuk dapat mengembangkan usaha mereka. Sedangkan bagi pelaku usaha sendiri agar lebih proaktif dalam meningkatkan pengetahuan dan kemampuan diri dalam rangka untuk mengembbangkan usaha. 


\section{DAFTAR PUSTAKA}

Anonim, 2006. Pengukuran dan Analisis Ekonomi Kinerja Penyerapan Tenaga Kerja, Nilai Tambah UKM serta Peranannya Menurut Harga Konstan dan Berlaku Tahun 2006, Kerjasama Badan Pusat Statistik dengan Program Peningkatan Kualitas Pelayanan Publik, Kementerian Koperasi dan UKM. Jakarta.

Anonim, 2007. National Life Finance Corporation, Jepang.

Anonim, 2007. New Business Actualization Plan, MOEA Taipei.

Arikunto, S. 1998. Prosedur Penelitian: Suatu Pendekatan Praktek, Rineka Cipta Jakarta.

Asmara, Anjal, Anie. 2004. Pola Pemasaran Yang Efektif Untuk UKM. Makalah disampaikan pada Seminar UKM Strategi Pengembangan Usaha Kecil Menengah dalam Rangka Menghadapi Persaingan Global, Yogyakarta.

Azwar, S. 2003b. Reliabilitas dan Validitas. Pustaka Pelajar Yogyakarta.

Berry, A., E. Rodriquez, dan H. Sandeem. 2001. Small and Medium Enterprises Dynamics in Indonesia, Bulletin of Indonesian Economic Studies 37 (3): 363-384. http://www.ekonomirakyat.org.

Burhan, Bungin. 2003. Metode Penelitian Kualitatif, PT. Raja Grafindo Persada Jakarta

Chandra, Purdi, E. 2004. Trik Bisnis Menuju Sukses, CV. Grafika Indah Yogyakarta.

Endang, Sri, Nuryani. 2004. Peran Pemerintah Dalam Pengembangan UKM Menghadapi Pasar Global, Makalah disampaikan pada Seminar UKM Strategi Pengembangan Usaha Kecil Menengah Dalam Rangka Menghadapi Persaingan Global, Yogyakarta.

Ernani, Hadiyati. 2010. Kemitraan UMKM, Teori dan Aplikasi BUMN-Bank, Bayumedia Publishing.

Ernawati. 2002. Upaya Meningkatkan Peran UKM, Warta Kemitraan Bagi Pengembangan Ekonomi Lokal, (KPEL, Jakarta, Edisi Oktober Bappenas, UNDP, UN-HABITAT).

Fakih, Mansour. 2003. Runtuhnya Teori Pembangunan Dan Globalisasi, Insist Press Yogyakarta.

Hakim, A. 2001. Statistik Induktif, Ekonisia Yogyakarta.

Hamadi. 2005. Metode Penelitian Kualitatif. Aplikasi praktis pembuatan proposal dan laporan Penelitian, Universitas Muhamadiaya Malang. Edisi III. 
Hasan, M., I, 2002. Pokok-Pokok Materi Metodologi Penelitian \& Aplikasinya, Ghalia Indonesia Jakarta.

Hasanullah. 1997. Peranan PPUK Bank Indonesia Dalam Pemberian KUK oleh Perbankan Di Indonesia, Jurnal Magister Manajemen. No. 26 Badan Penerbit IPWI Jakarta.

Hikmat, Harry. 2010. Strategi Pemberdayaan Masyarakat, Edisi Revisi HUP.

Hinsatopa, Simatupang, 2008. Pengaruh Kebijakan Pemerintah, Kewirausahaan (Entrepreneur) terhadap Produktivitas Usaha dan Keberlanjutan (Sastairzability) Pekebun Kecil pada Pndustri Keiapa Sawit di Provinsi Riau (Studi pada Perkebunan Kelapa Sawit di Provinsi Riau), Jurnal Aplikasi Manajemen Vol. 7. No. 1.

Karsidi, Ravik. 1988. Perorganisasian Potensi Pembangunan Masyarakat,SuatuModel Menumbuhkan Partisipasi, Makalah. KNPI Surakarta.

Miles, M., B. \& Huberman, A., M. 1992. Analisis data kualitatif: Buku sumber tentang metode-metode baru, Universitas Indonesia Jakarta.

Nazara, Suahasil. 1997. Garis kemiskinan dan Pengentasan kemiskinan: Kerangka Teori Foster-Greer-Thorbecke, Prisma.

Soegiarto, Eddy, K. 2006. Usaha Mikro dan Kecil, Kesempatan Kerja dan Pembangunan Ekonomi Kota Samarinda, Disajikan pada seminar MKPD Program Doktor Ilmu Ekonomi Universitas 17 Agustus 1945. Surabaya.

Stephenson, K., Arinaitwe. 2006. Factors Constraining the Growth and Survival of Small Scale Businesses. A Developing Countries Analysis. Journal of American Academy of Business, Cambridge, http://.proquest.com/ pqdweb/

Suryana, 2009. Kewirausahaan Pedoman Praktis:Kiat dan Proses Menuju Sukses, Edisi 3. Salemba Empat.

Suryana Yuyus dan Kartib Bayu, 2010. Kewirusahaan, Pendekatan Karakteristik Wirausahawan Sukses, Kencana Prenada Media Group.

Tambunan, Tulus. 2006. The Performance of Small Enterprises during economic Crisis: Evidence Indonesia. Journal of Small Business Management, Milwaukee. 